\title{
Hubungan antara Rasio Neutrofil-Limfosit dan Skor Sequencial Organ Failure Assesment pada Pasien yang Dirawat di Ruang Intensive Care Unit
}

\author{
Adi Nugroho, ${ }^{1}$ Suwarman, ${ }^{2}$ A. Muthalib Nawawi ${ }^{2}$ \\ ${ }^{1}$ Unit Kamar Bedah dan ICU, RS Umum Daerah Depati Hamzah Kota Pangkal Pinang Bangka \\ Belitung, ${ }^{2}$ Departemen Anestesiologi dan Terapi Intensif Fakultas Kedokteran Universitas \\ Padjadjaran/Rumah Sakit Dr. Hasan Sadikin Bandung
}

\begin{abstract}
Abstrak
Respons fisiologis sistem imunitas terhadap inflamasi sistemik adalah peningkatan jumlah neutrofil dan penurunan jumlah limfosit atau peningkatan rasio neurofil-limfosit (RNL). Penelitian ini bertujuan untuk melihat hubungan inflamasi sistemik yang ditandai peningkatan RNL terhadap kegagalan fungsi organ ditandai dengan skor sequencial organ failure assessment (SOFA) pada pasien yang dirawat di Intensive Care Unit (ICU). Penelitian ini adalah penelitian observasional dengan rancangan penelitian cross sectional. Penelitian dilakukan dengan mengobsevasi RNL dan skor SOFA pada jam ke-0, jam ke-24, dan jam ke-48 dari 78 pasien yang dirawat di ICU Rumah Sakit Dr. Hasan Sadikin Bandung periode Desember 2012-Februari 2013 yang terbagi ke dalam 3 kategori sepsis A, B, dan C. Data penelitian dianalisis menggunakan analisis bivariabel dengan Uji Korelasi Pearson dan Spearman. Hasil penelitian menunjukkan hubungan antara RNL dan skor SOFA terhadap kategori sepsis masing-masing $(\mathrm{p}<0,001)$. Uji Korelasi Pearson didapatkan hubungan antara RNL dan skor SOFA $(p<0,05 ; R=0,63)$. Simpulan, terdapat hubungan antara keadaan inflamasi sistemik yang ditandai dengan RNL dan kegagalan fungsi organ yang ditandai dengan skor SOFA pada pasien yang dirawat di ICU RS Dr. Hasan Sadikin Bandung.
\end{abstract}

Kata kunci: Intensive care unit, rasio netrofit-limfosit, sequencial organ failure assesment

\section{Relationship between Neutrophil Lymphocyte Ratio and Sequential Organ Failure Assesment Score in the Intensive Care Unit Patients}

\begin{abstract}
Physiological response of immune system against systemic inflammation involves an increased level of neutrophils and a reduction of lymphocyte or an increase of neutrophil-lymphocyte ratio (RNL). The aim of this study was to identify the relationship between systemic inflammation, characterized by increasing in RNL on organ malfunction, assessed by sequential organ failure assessment (SOFA) score in Intensive Care Unit (ICU) patients. This study was a observational study with cross sectional design. This study was conducted by observing RNL and SOFA score at $0.24^{\text {th }}$ and $48^{\text {th }}$ hour of 78 patients treated in the ICU Dr. Hasan Sadikin Hospital Bandung in December 2012-February 2013. The patients were divided into 3 categories of sepsis A, B and C. This study showed that there was a relationship between RNL, SOFA scores and sepsis categories $(p<0.001)$. Pearson Correlation Test showed that there was relationship between RNL and SOFA scores $(\mathrm{p}<0.05, \mathrm{R}=0.63)$. In conclusion, there is a relationship between systemic inflammatory condition, characterized by RNL and organ failure, characterized by the SOFA score, in patients treated in the ICU Dr. Hasan Sadikin Hospital Bandung.
\end{abstract}

Key words: Intensive care unit, neutrophil-lymphocyte ratio, sequential organ failure assesment

Korespondensi: Adi Nugroho, dr., SpAn, Unit Kamar Bedah dan ICU, RS Umum Daerah Depati Hamzah Kota Pangkal Pinang Bangka Belitung, Jl. Soekarno Hatta Pangkal Pinang Bangka, Tlp 0717-422693, Mobile 0813-43155826, Email adinugroho_fk98@yahoo.com-nugrohoadi.fk98@gmail.com 


\section{Pendahuluan}

Penurunan dan kegagalan fungsi organ sering ditemukan pada pasien dengan kasus systemic inflammation responses syndrome (SIRS) serta sepsis yang dirawat di unit perawatan intensif atau intensive care unit (ICU), hal ini ditenggarai diakibatkan antara lain karena aktivitas sistem imun yang tidak seimbang antara sitokin proinflamasi dan antiinflamasi. ${ }^{1,2}$

Pada SIRS dan sepsis telah diteliti berbagai parameter dan sistem penilaian atau skoring guna menegakkan diagnosis, memperkirakan prognosis, serta menilai/memantau perbaikan dan juga perburukan pasien sepsis. Parameter yang telah diteliti pada kasus ini yaitu kondisi klinis seperti suhu, laju nadi, tekanan darah, serta pernapasan, juga beberapa pemeriksaan penunjang antara lain jumlah leukosit, kadar protein inflamasi akut seperti protein reaktif $\mathrm{C}$ (C-reactive protein/CRP), prokalsitonin serta interleukin-6. ${ }^{3,4}$ Parameter klinis serta jumlah leukosit telah dijadikan sebagai penanda SIRS dan juga sepsis, tetapi penggunaan parameter penunjang lain masih terhambat oleh kendala sensitivitas, spesifisitas, kepraktisan, dan juga pembiayaan.

Salah satu respons fisiologis pada sistem imunitas terhadap inflamasi sistemik adalah peningkatan jumlah neutrofil serta penurunan jumlah limfosit. ${ }^{3} \mathrm{Hal}$ ini disebabkan perubahan dinamika dan regulasi apoptosis pada keadaan inflamasi sistemik jika dibandingkan dengan keadaan noninflamasi.

Pada penelitian respons imunitas terhadap proses inflamasi, pada kelompok pasien yang diberikan endotoksemia, setelah 4-6 jam akan terjadi penurunan jumlah limfosit sekitar $85 \%$ dan neutrofil meningkat sekitar 300\%. ${ }^{5}$

Penundaan proses apoptosis neutrofil akan berakibat pemanjangan fungsi neutrofil dalam proses inflamasi sekaligus akan memperlama proses elaborasi metabolik toksik. Sebaliknya, peningkatan apoptosis limfosit akan berakibat pada penurunan efektor inflamasi dan juga imunosupresi. ${ }^{2,6}$

Metabolik toksik yang dilepaskan neutrofil teraktifasi dan sitokin inflamasi akan merusak jaringan serta menyebabkan gangguan fungsi organ. Selain itu, apoptosis dari limfosit akan mengakibatkan imunosupresi sistem imunitas adaptif sehingga akan mudah terserang infeksi nosokomial dan juga bakteri oportunistik yang mencetuskan reaksi inflamasi sistemik lebih lanjut. $^{7}$

Akibat peningkatan jumlah neutrofil dan penurunan jumlah limfosit, akan menyebabkan terjadi peningkatan rasio absolut neutrofil dan limfosit apabila dibandingkan dengan pasien tanpa reaksi inflamasi sistemik.

Morbiditas dan mortalitas di ICU ditentukan oleh perkembangan kegagalan fungsi organ yang terjadi. Kerusakan dan kegagalan fungsi organ ini dapat dimonitor antara lain dengan menggunakan skor Sequencial Organ Failure Assessment (SOFA). Jumlah skor SOFA rata-rata pada 48 jam pertama merupakan indikator prognosis yang cukup baik untuk memprediksi keluaran pasien. $^{8}$

\section{Subjek dan Metode}

Penelitian ini adalah penelitian observasional dengan mempergunakan rancangan penelitian cross sectional dengan melakukan pengukuran variabel independen dan juga dependen pada waktu bersamaan.

Subjek penelitian ialah pasien yang dirawat di ICU Rumah Sakit Dr. Hasan Sadikin (RSHS) Bandung periode Desember 2012-Februari 2013. Kriteria inklusi yaitu pasien yang telah dirawat di ICU lebih dari 24 jam dan bersedia mengikuti penelitian dan juga menandatangani formulir persetujuan. Kriteria eksklusi ialah pasien yang sedang mendapatkan kemoterapi dan juga pasien dengan keganasan sel darah. Pengeluaran sampel penelitian akan dilakukan apabila subjek tidak mencapai hari perawatan 48 jam pertama.

Besar sampel minimal 78 orang ditentukan berdasarkan rumus untuk uji hipotesis dengan koefisien korelasi $r$.

Uji normalitas data numerik untuk melihat distribusi data dilakukan dengan menggunakan One Sample Kolmogorof Test dengan Lillefors Significance Correction. Analisis bivariabel untuk menganalisis korelasi antara nilai RNL dan skor SOFA pada data berdistribusi normal 
menggunakan Uji Korelasi Pearson sedangkan untuk data yang tidak berdistribusi normal menggunakan Uji Korelasi Spearman. Analisis multivariabel dilakukan untuk mengendalikan faktor perancu dengan menggunakan multiple linear regression test. Analisis data dilakukan mempergunakan program statistical product and service solution (SPSS) for windows versi 17.0 dengan derajat kepercayaan 95\%, nilai $\mathrm{p} \leq 0,005$ dianggap bermakna.

Setelah mendapat persetujuan dari Komite Etik Penelitian Kesehatan Rumah Sakit Dr. Hasan Sadikin Bandung/Fakultas Kedokteran Universitas Padjadjaran, pasien yang masuk ke dalam kriteria inklusi memperoleh tindakan sesuai dengan protokol terapi yang berlaku di ICU. Pasien atau keluarga pasien diberikan penjelasan tentang proses penelitian yang akan dijalani dan diberikan lembar persetujuan.

Evaluasi SOFA dilakukan pada saat pasien masuk ke ICU (jam ke-0), kemudian dilakukan pemeriksaan terhadap darah rutin, hitung jenis persentase neutrofil, limfosit, rasio persentase neutrofil-limfosit yang diulang kembali pada jam ke-24 dan ke-48. Pasien dibagi ke dalam 3 (tiga) kelompok, yaitu sepsis A, B, dan C untuk kemudian dilakukan analisis korelasi. Selama perawatan pasien mendapatkan tindakan lain sesuai dengan indikasi dan juga protokol terapi yang telah ditetapkan oleh dokter penanggung jawab ICU yang bertugas.

\section{Hasil}

Penelitian dilakukan pada pasien di ICU Rumah Sakit Dr. Hasan Sadikin Bandung. Usia rata-rata sampel penelitian ialah 41,63 tahun dengan usia termuda 17 tahun dan usia tertua 76 tahun. Sebagian besar subjek yang dirawat di ICU yakni 46 orang (59\%) laki-laki dan 32 orang $(41 \%)$ perempuan. Tipe pasien yang dirawat di ICU sebagian besar 54 orang (69\%) adalah tipe surgical sedangkan 24 orang (31\%) adalah tipe medical (Tabel 1).

Indeks massa tubuh (body mass index/BMI) pasien yang dirawat di ICU adalah $23,86 \mathrm{~kg} / \mathrm{m}^{2}$ dengan BMI terendah $18 \mathrm{~kg} / \mathrm{m}^{2}$ dan tertinggi $30 \mathrm{~kg} / \mathrm{m}^{2}$, hasil pemeriksaan kadar albumin rata-rata pasien yang dirawat di ICU adalah
Tabel 1 Karakteristik Umum Subjek Penelitian

\begin{tabular}{lccc}
\hline Variabel & n & $\begin{array}{c}\text { Rata-rata } \\
\text { (SD) }\end{array}$ & $\begin{array}{c}\text { Median } \\
\text { (Rentang) }\end{array}$ \\
\hline Usia (tahun) & & 41,63 & 41,5 \\
& & $(15,33)$ & $(17-76)$ \\
$\begin{array}{c}\text { Jenis kelamin } \\
\text { Laki-laki }\end{array}$ & 46 & & \\
Perempuan & 32 & & \\
$\begin{array}{c}\text { Tipe pasien } \\
\text { Surgical }\end{array}$ & 54 & & \\
$\quad$ Medical & 24 & & \\
BMI & & 23,86 & 24 \\
& $(3,26)$ & $(18-30)$ \\
Albumin & & 3,13 & 3,05 \\
& & $(0,68)$ & $(1,5-4,8)$ \\
Leukosit & & 15,121 & 15 \\
(ribu) $/ \mathrm{mm}^{3}$ & & $(5,9)$ & $(3,4-38)$ \\
\hline
\end{tabular}

3,13 g/dL dengan kadar albumin terendah 1,5 dan kadar albumin tertinggi 4,8. Nilai leukosit rata-rata pasien yang dirawat di ICU adalah $15.121 / \mathrm{mm}^{3}$ dengan nilai leukosit terendah $3.400 / \mathrm{mm}^{3}$ dan tertinggi $38.000 / \mathrm{mm}^{3}$ (Tabel $1)$.

Sebelum analisis statistik, dilakukan dahulu uji normalitas terhadap data numerik untuk mengetahui distribusi data, baik terhadap RNL ataupun skor SOFA. Uji normalitas dilakukan dengan menggunakan One Sample Kolmogorov Smirnov Test untuk besar sampel $>50$.

Hasil uji normalitas dengan menggunakan One Sample Kolmogorov Smirnov with Lilliefors Significance Correction Test memperlihatkan bahwa distribusi data RNL serta skor SOFA adalah normal ( $p>0,05$; Tabel 2), sehingga untuk uji bivariabel digunakan independent $T$ test dan analysis of variance (ANOVA) test.

Karakteristik skor SOFA serta faktor RNL pada pasien yang dirawat di ICU menunjukkan bahwa skor SOFA rata-rata 6,39 dengan nilai terkecil 0,33 dan skor SOFA tertinggi 14,33. RNL rata-rata 7,83 dengan nilai terkecil 3,72 dan tertinggi 15,75 .

Hasil uji statistik mempergunakan ANOVA dengan tingkat kepercayaan 95\% adalah tidak terdapat hubungan bermakna usia, BMI, dan albumin dengan kategori sepsis pasien yang dirawat di ICU pada pengamatan selama 48 jam pertama dengan berturut-turut $\mathrm{p}=0,131$; $\mathrm{p}=0,291$; dan $\mathrm{p}=0,09$. Selain itu, pemeriksaan 
Tabel 2 Hubungan Karakteristik berdasarkan Usia, Jenis Kelamin, Tipe Pasien, BMI, Albumin, dan Leukosit dengan Kategori Sepsis pada Pasien yang Dirawat di ICU

\begin{tabular}{lcccc}
\hline \multicolumn{1}{c}{ Variabel } & Sepsis A & Sepsis B & Sepsis C & Nilai p \\
\hline Usia, mean (SD) & $47,64(12,63)$ & $38,55(15,91)$ & $41,54(15,5)$ & $\left.0,131^{*}\right)$ \\
Jenis kelamin, n (\%) & & & & $\left.0,217^{* *}\right)$ \\
$\quad$ Laki-laki & $8(17 \%)$ & $18(39 \%)$ & $20(44 \%)$ & \\
$\quad$ Perempuan & $9(28 \%)$ & $15(47 \%)$ & $8(25 \%)$ & \\
Tipe pasien, n (\%) & & & & $\left.0,432^{* *}\right)$ \\
Surgical & $11(21 \%)$ & $25(47 \%)$ & $17(32 \%)$ & \\
Medical & $6(24 \%)$ & $8(32 \%)$ & $11(44 \%)$ & \\
BMI, mean (SD) & $24,8(2,99)$ & $24(3,8)$ & $23,3(3,69)$ & $\left.0,291^{*}\right)$ \\
Albumin, mean (SD) & $3,36(0,49)$ & $2,8(1,5)$ & $2,81(0,71)$ & $\left.0,09^{*}\right)$ \\
Leukosit, mean (SD) & $13,1(4,3)$ & $14,6(4,3)$ & $16,99(7,8)$ & $\left.0,08^{*}\right)$ \\
\hline
\end{tabular}

Keterangan: ${ }^{*}$ uji ANOVA ${ }^{* *}$ uji chi-kuadrat

leukosit yang sering dilakukan pada pasien sepsis juga tidak memiliki hubungan dengan kategori sepsis ( $\mathrm{p}=0,08$; Tabel 2 ).

Hasil uji statistik menggunakan tes chi-kuadrat dengan tingkat kepercayaan 95\%, didapatkan bahwa tidak terdapat hubungan bermakna tipe pasien serta jenis kelamin dengan kategori sepsis pada pasien yang dirawat di ICU saat pengamatan 48 jam pertama $(\mathrm{p}=0,432$ dan $\mathrm{p}=0,217$; Tabel 2).

Hasil uji statistik ANOVA dengan tingkat kepercayaan 95\%, menunjukkan hubungan bermakna antara skor SOFA dan kategori sepsis pada pasien yang dirawat di ICU $(\mathrm{p}<0,001)$, juga terdapat hubungan bermakna antara RNL dan kategori sepsis $(\mathrm{p}<0,001$; Tabel 3$)$.

Uji statistik mempergunakan independent T-test dan tingkat kepercayaan 95\%, terdapat hubungan yang bermakna antara albumin dan pengelompokan RNL pada pasien yang dirawat di ICU $(p=0,025)$. Tidak terdapat hubungan bermakna usia dan BMI dengan kategori RNL terhadap pasien yang dirawat di ICU $(\mathrm{p}=0,063$ dan $p=0,58$ ). Jumlah leukosit pasien di ICU juga tidak memiliki hubungan yang bermakna dengan pengelompokan RNL $(p=0,432$; Tabel 4).

Hasil uji statistik dengan mempergunakan chi-kuadrat dengan tingkat kepercayaan 95\%, didapatkan hubungan antara kategori sepsis dan pengelompokan RNL pada pasien yang dirawat di ICU $(p<0,001)$, namun ternyata tidak terdapat hubungan bermakna jenis kelamin dan tipe pasien dengan pengelompokan RNL ( $\mathrm{p}=0,548$ dan $\mathrm{p}=0,067$; Tabel 4).

Hasil Uji Pearson Correlation pada tingkat kepercayaan 95\%, menunjukkan ada hubungan bermakna antara RNL dan skor SOFA pada pasien yang dirawat di ICU $(p<0,001)$, tetapi tidak didapatkan hubungan bermakna antara

Tabel 3 Hubungan RNL dan Skor SOFA dengan Jenis Sepsis pada Pasien yang Dirawat di ICU

\begin{tabular}{lcccc}
\hline \multirow{2}{*}{ Variabel } & Sepsis A & Sepsis B & Sepsis C & \multirow{2}{*}{ Nilai p } \\
\cline { 2 - 4 } & Rata-rata (SD) & Rata-rata (SD) & Rata-rata (SD) & \\
\hline Skor SOFA & $2,96(2,94)$ & $5,9(2,5)$ & $9,1(2,9)$ & $\left.<0,001^{*}\right)$ \\
RNL & $5,4(1,04)$ & $7,4(1,71)$ & $9,8(2,62)$ & $\left.<0,001^{*}\right)$ \\
\hline
\end{tabular}

Keterangan: *) uji ANOVA 
Tabel 4 Hubungan Usia , Jenis Kelamin, Tipe Pasien, BMI, Albumin, Leukosit, dan Kategori Sepsis dengan Kelompok RNL pada Pasien yang Dirawat Di ICU

\begin{tabular}{|c|c|c|c|c|c|}
\hline \multirow{2}{*}{ Parameter } & \multicolumn{2}{|c|}{ RNL A } & \multicolumn{2}{|c|}{ RNL B } & \multirow{2}{*}{ Nilai p } \\
\hline & Mean (SD) & $\mathbf{n}$ & Mean (SD) & $\mathbf{n}$ & \\
\hline Usia (tahun) & $55,67(10,44)$ & & $39,80(14,95)$ & & $0,063^{*}$ \\
\hline Jenis kelamin & & & & & $0,548^{*}$ \\
\hline Laki-laki & & $5(11 \%)$ & & 41 (89\%) & \\
\hline Perempuan & & $4(12 \%)$ & & $28(88 \%)$ & \\
\hline Tipe pasien & & & & & $\left.0,067^{* *}\right)$ \\
\hline Surgical & & $3(6 \%)$ & & $50(94 \%)$ & \\
\hline Medical & & $6(24 \%)$ & & $19(76 \%)$ & \\
\hline BMI & $24,89(2,9)$ & & $24(3,7)$ & & $\left.0,58^{*}\right)$ \\
\hline Albumin & $3,4(0,43)$ & & $2,9(0,6)$ & & $0,025^{*}$ \\
\hline Kategori sepsis & & & & & $<0,001^{* *}$ \\
\hline Sepsis A & & 7 & & 10 & \\
\hline Sepsis B & & 2 & & 31 & \\
\hline Sepsis C & & 0 & & 29 & \\
\hline Leukosit & $13,7(5,2)$ & & & $15,3(5,9)$ & $0,432^{*}$ \\
\hline
\end{tabular}

Ket: * Independent T-test ${ }^{* *}$ uji chi-kuadrat

usia dan skor SOFA ( $\mathrm{p}=0,854)$. Tidak terdapat hubungan bermakna antara BMI dan skor SOFA ( $\mathrm{p}=0,231)$. Tidak terdapat hubungan yang bermakna antara albumin dan skor SOFA $(\mathrm{p}=0,056)$ dan juga tidak terdapat hubungan bermakna antara jumlah leukosit dan skor SOFA ( $\mathrm{p}=0,114$; Tabel 5).

Hasil uji statistik ANOVA ternyata terdapat hubungan bermakna antara kategori sepsis dan skor SOFA pada pasien di ICU $(\mathrm{p}<0,001)$, namun hasil uji statistik dengan menggunakan independent T-test ternyata tidak ada hubungan bermakna antara jenis kelamin dan skor SOFA pada pasien yang dirawat di ICU dengan nilai $\mathrm{p}=0,125$ serta tidak terdapat hubungan yang bermakna antara tipe pasien dan skor SOFA $(\mathrm{p}=0,316$; Tabel 5).

Uji statistik menggunakan multiple linear regression dengan tingkat kepercayaan 95\%, menunjukkan hubungan bermakna nilai RNL dengan skor SOFA pada pasien yang dirawat di ICU dengan mempertimbangkan variabel tingkat sepsis $(\mathrm{p}<0,001$; Tabel 6).

Hasil Uji Statistik Pearson Correlation pada tingkat kepercayaan 95\%, terdapat hubungan bermakna antara RNL dan skor SOFA pada pasien yang dirawat di ICU Rumah Sakit Dr. Hasan Sadikin Bandung ( $\mathrm{p}<0,001$; Tabel 6).

\section{Pembahasan}

Penelitian telah dilakukan terhadap 78 pasien yang dirawat di ICU Rumah Sakit Dr. Hasan Sadikin terdiri atas 54 pasien surgical dan 25 pasien medical. Dari 78 pasien yang diamati dikelompokkan menjadi 3 kelompok kategori sepsis A, B, dan C masing-masing 18,33 , dan 28 orang.

RNL dibagi menjadi dua kelompok yaitu nilai $R N L \leq 5$ dan nilai $R N L>5$, secara berurutan pada penelitian ini disebut dengan RNL A dan RNL B. Pengelompokan RNL ini juga dilakukan pada penelitian Zahorec $^{3}$ pada pasien ICUonkologi. Pada penelitian tersebut digunakan patokan nilai NLSF $\leq 5$ pada keadaan fisiologis dan $>5$ pada keadaan stres inflamasi sistemik.

Pada penjabaran hasil penelitian ini, pada Tabel 6 didapatkan pengelompokan RNL ini 
Tabel 5 Hubungan Antara Usia, Jenis Kelamin, Tipe Pasien, BMI, Albumin, Kategori Sepsis, Leukosit, dan RNL terhadap Skor SOFA pada Pasien yang Dirawat di ICU

\begin{tabular}{|c|c|c|c|c|c|}
\hline Variabel & \multicolumn{2}{|c|}{$\begin{array}{c}\text { Skor } \\
\text { Rata-rata (SD) }\end{array}$} & $\mathbf{R}$ & \multicolumn{2}{|c|}{ Nilai p } \\
\hline \multicolumn{3}{|l|}{ Usia (tahun) } & $-0,02$ & & \\
\hline \multicolumn{3}{|l|}{ Jenis kelamin } & & \multicolumn{2}{|c|}{$0,125^{* *}$} \\
\hline Laki-laki & \multicolumn{2}{|c|}{$6,88(3,59)$} & & & \\
\hline Perempuan & \multicolumn{2}{|c|}{$5,69(2,89)$} & & & \\
\hline \multicolumn{3}{|l|}{ Tipe pasien } & & \multicolumn{2}{|c|}{$0,316^{* *}$} \\
\hline Surgical & \multicolumn{2}{|c|}{$6,14(3,10)$} & & & \\
\hline Medical & \multicolumn{2}{|c|}{$6,97(3,86)$} & & & \\
\hline \multicolumn{3}{|l|}{ BMI } & $-0,19$ & \multicolumn{2}{|c|}{$0,231^{*}$} \\
\hline \multicolumn{3}{|l|}{ Albumin } & $-0,22$ & \multicolumn{2}{|c|}{$0,056^{*}$} \\
\hline \multicolumn{3}{|l|}{ Kategori sepsis } & & \multicolumn{2}{|c|}{$<0,001^{* * * j}$} \\
\hline Sepsis A & \multicolumn{2}{|c|}{$2,96(1,47)$} & & & \\
\hline Sepsis B & \multicolumn{2}{|c|}{$5,91(2,52)$} & & & \\
\hline Sepsis C & \multicolumn{2}{|c|}{$9,05(2,86)$} & & & \\
\hline \multicolumn{3}{|l|}{ RNL } & 0,63 & \multicolumn{2}{|c|}{$<0,001^{*}$} \\
\hline \multicolumn{3}{|l|}{ Leukosit } & 0,18 & \multicolumn{2}{|c|}{$\left.0,114^{*}\right)$} \\
\hline \multicolumn{6}{|c|}{$\begin{array}{l}\text { Keterangan: ") Pearson Correlation Test ") Independent T-test }{ }^{* *} \text { uji ANOVA } \\
\text { R= koefisien Pearson Correlation }\end{array}$} \\
\hline \multicolumn{6}{|c|}{$\begin{array}{lr}\text { berhubungan dengan kategori sepsis dengan } & \text { dengan nilai } r=0,63 . \\
\text { nilai } \mathrm{p}<0,001 . \text { Melalui analisis penghitungan } & \text { Hal ini menjelaskan bahwa pada inflamasi } \\
\text { Pearson Correlation, ternyata RNL mempunyai } & \text { sistemik luas seperti pada sepsis, nilai RNL } \\
\text { hubungan dengan skor SOFA }(\mathrm{p}<0,001) \text {. Selain } & \text { memiliki korelasi terhadap jenis sepsis yang } \\
\text { itu, hubungan ini memiliki kekuatan yang baik } & \text { terjadi. Di samping itu, analisis hubungan RNL }\end{array}$} \\
\hline \multicolumn{6}{|c|}{$\begin{array}{l}\text { Tabel } 6 \text { Hubungan Nilai RNL dengan Skor SOFA Pasien yang Dirawat di ICU dengan } \\
\text { Mempertimbangkan Variabel Lain }\end{array}$} \\
\hline Variabel & B & SE & $\mathbf{R}$ & $\mathbf{R}^{2}$ & Nilai p \\
\hline Awal & & & 0,73 & 0,54 & $<0,001$ \\
\hline RNL & 0,417 & 0,135 & & & 0,003 \\
\hline Albumin & $-0,427$ & 0,395 & & & 0,283 \\
\hline Sepsis & 2,050 & 0,469 & & & $<0,001$ \\
\hline Konstanta & 2,135 & & & & \\
\hline Akhir & & & 0,73 & 0,53 & $<0,001$ \\
\hline RNL & 0,419 & 0,135 & & & 0,003 \\
\hline Sepsis & 2,117 & 0,466 & & & $<0,001$ \\
\hline Konstanta & $-0,569$ & & & & \\
\hline
\end{tabular}

Keterangan: ${ }^{*}$ Linear regression test

$\mathrm{B}=$ kesalahan standar koefisien regresi, $\mathrm{SE}=$ kesalahan standar estimasi, $\mathrm{R}=$ koefisien

Pearson Correlation, $\mathrm{R}^{2}=$ koefisien determinasi 
dan skor SOFA juga didukung oleh hubungan antara kategori sepsis yang terjadi terhadap skor SOFA $(p<0,001)$, dan RNL juga memiliki hubungan erat terhadap kategori sepsis yang terjadi (Tabel 5).

Korelasi RNL dengan kategori sepsis ini juga ditemukan pada penelitian oleh Zahorec. ${ }^{3}$ Dari penelitian tersebut dinyatakan bahwa korelasi penurunan jumlah neutrofil dan peningkatan jumlah limfosit terhadap perbaikan kondisi klinis pasien SIRS dan sepsis.

Penjabaran tersebut menunjukkan bahwa pada inflamasi sistemik berat seperti severe sepsis serta syok septik, sistem imunitas tubuh berespons dengan terjadi peningkatan rasio neutrofil limfosit lebih besar bila dibandingkan dengan kondisi inflamasi sistemik yang ringan ataupun kondisi tubuh tanpa inflamasi.

Salah satu respons fisiologis pada sistem imunitas terhadap inflamasi sistemik adalah peningkatan jumlah neutrofil dan penurunan jumlah limfosit. ${ }^{3} \mathrm{Hal}$ ini disebabkan perubahan dinamika dan regulasi apoptosis pada keadaan inflamasi sistemik bila dibandingkan dengan keadaan noninflamasi.

Pada penelitian respons imunitas terhadap proses inflamasi pada kelompok pasien yang diberikan endotoksemia, ternyata setelah 4-6 jam akan terjadi penurunan jumlah limfosit sekitar $85 \%$ sedangkan neutrofil meningkat sekitar 300\%. ${ }^{5}$

Penundaan proses apoptosis neutrofil akan berakibat pemanjangan fungsi neutrofil dalam proses inflamasi serta memperlama elaborasi metabolik toksik, sebaliknya apoptosis limfosit yang meningkat berakibat penurunan efektor inflamasi dan menyebabkan imunosupresi. ${ }^{2,6}$

Metabolik toksik yang dilepaskan neutrofil yang teraktifasi dan ditambah dengan sitokin inflamasi akan merusak jaringan serta fungsi organ. Di samping itu, proses apoptosis limfosit mengakibatkan imunosupresi sistem imunitas adaptif sehingga akan mudah terserang infeksi nosokomial dan juga bakteri oportunistik yang akan mencetuskan reaksi inflamasi sistemik lebih lanjut. ${ }^{9}$

Akibat peningkatan jumlah neutrofil serta penurunan jumlah limfosit akan meningkatkan nilai rasio absolut antara neutrofil dan limfosit jika dibandingkan dengan pasien tanpa reaksi inflamasi sistemik. Sejalan dengan peningkatan rasio neutrofil limfosit, maka risiko morbiditas dan mortalitas pasien yang ditandai dengan kerusakan dan kegagalan fungsi organ akan semakin meningkat.

Hasil yang didapatkan pada penelitian ini semakin menguatkan landasan teori dan hasilhasil penelitian yang lain bahwa rasio neutrofil limfosit mempunyai korelasi dengan kondisi klinis pasien sepsis.

\section{Simpulan}

Berdasarkan hasil penelitian ini disimpulkan bahwa terdapat hubungan antara rasio RNL dan skor SOFA, serta antara nilai RNL $\leq 5$ dan RNL $>5$ dengan kategori sepsis yang terjadi pada pasien yang dirawat di ICU.

\section{Daftar Pustaka}

1. Marino PL. Infection, inflamation and multiorgan injury. Dalam: Howland RD, Mycek M, penyunting. The ICU book. Edisi ke-3. New York: Liipincot Williams \& Wilkins; 2007. hlm. 737-48.

2. Xing-hai Chen, Yong-jie Yin, Jing-xiao Zhang. Sepsis and immune response. World J Emerg Med. 2011;2:88-92.

3. Zahorec R. Ratio of neutrophil to lymphocite counts-rapid and simple parameter of systemic inflamation and stress in critically ill. Bratisl Lek Listy. 2001;102(1):5-14.

4. Jager CPC, Wijk PTL, Mathoera RB, Leuvink JJ, Poll T, Wever PC. Lymphocytopenia and neutrophil-lymphocyte count ratio predict bacteriemia better than conventional infection markers in an emergency care unit. Crit Care Med. 2010;14:1-8.

5. Jilma B, Blan A, Pernerstorfer T, Stolawetz P, dkk. Regulation of adhesion molecule during human endotoxaemia. Am J Resp Crit Care Med. 1999;159:857-63.

6. Fabiano PS, Victor N. Cell death during sepsis : integration of disintegration in the inflamatory response to overwhelming 
196 | Jurnal Anestesi Perioperatif

infection. Apoptosis. 2009:14:509-21.

7. Cahterin MD. Sel darah putih. Dalam: Sylvia AP, Lorraine MW, penyunting. Patofisiologi: konsep klinis proses-proses penyakit. Edisi ke-4. Jakarta: EGC; 1995. hlm. 244-6.

8. Fereira FL, Bota DP, Bross A, Melot C,
Vincent JL. Serial evaluation of the SOFA score to predict outcome in critically ill patient. JAMA. 2001:286(14):1-5.

9. Jacqueline P, Bryony C. An overview of the immune system. Lancet. 2001;357:177790. 